\title{
Marzena Myślińska
}

Maria Curie-Sklodowska University

marzenamyslinska@wp.pl

\section{The Processes of Application of Law and the Decision Making in Mediation Process}

Proces stosowania prawa a mediacyjny proces decyzyjny

\section{ABSTRACT}

Mediation is treated in many contemporary legal proceedings as a part of decision making process, also in the processes of application of law. The main question stated in the article concerns the separate nature of the mediation, uncomparable to the traditional view of the application of law. Is the mediation procedure only a specific and unnecessary part of the application of law process, or the distinct and necessary decision making unit which may replace the traditional, authoritative model of the application of law?

Keywords: mediation, decision making process, convergent discourse, application of law, the judicial type of application of law

\section{CONFLICTS, DISPUTES AND INSTITUTIONAL FORMS OF THEIR RESOLUTION}

Conflict is, beside neutrality and cooperation, one of the three universal patterns of social relations. ${ }^{1}$ Conflicts stem from interests and needs of the parties. ${ }^{2}$ Disclosure of conflict on the social forum and its exposure to social observation

${ }^{1}$ More on this issue: A. Korybski, Alternatywne rozwiazywanie sporów w USA, Lublin 1993, p. 18. The author understands conflict as "a system of juxtaposed behaviours of two social entities (persons, groups or organisations), with each party striving to achieve its own goals (interests) and encountering counteraction of the other party to the conflict". Ibidem, p. 20.

${ }^{2} \mathrm{H}$. Groszyk, A. Korybski, O pojęciu interesu w naukach prawnych (przeglad wybranej problematyki z perspektywy teoretyczno-prawnej), [in:] Pojęcie interesu w naukach prawnych, prawie stanowionym i orzecznictwie sadowym Polski i Ukrainy, eds. A. Korybski, M. Kostyckij, L. Leszczyński, Lublin 2006, p. 20. 
is associated with conflict's qualitative transformation into a dispute. ${ }^{3}$ If the social environment evaluates the dispute as destructive and posing a threat to the existing social relations, the environment may initiate activities aimed at forcing the parties to take appropriate steps concerning the course of the dispute, or to make the decision to end the dispute. ${ }^{4}$

The occurrence of disputes and their clear impact on social life is connected with the mechanisms of dispute control that are perceived as a process aimed controlling the dispute and its ending. The ending, in turn, may take the form of dispute resolution or adjudication regarding the dispute. ${ }^{5}$ Realisation of each of the forms takes place as a decision made as a consequence of the preceding process, conditioned by the features characterising the relevant form of dispute ending. Consequently, the decision making processes are in general characterised by arbitrary final decisions and compulsory enforcement of the decision. The imposition of the decision on its addressees may result from the conflict between the parties to the dispute and the consequent definition of the winner and the loser or an intervention of a third party that has the relevant authority over the parties

${ }^{3}$ More on this issue: K. Kurczewski, Spór i jego rozwiąanie, [in:] Konflikt i przystosowanie, Vol. IV, Warsaw 1979, pp. 10-11; A. Korybski, Alternatywne rozwiazywanie..., p. 26. It must further be added that the notion of dispute has been know since the Roman times and its traditional notion of "lis". Dispute is predominantly associated with private law and the branches of law that utilize the construct of claim or interest in order to shape the situation of dispute that a legal subject is in. In criminal law, the notion of dispute should be perceived from the perspective of this law's function and the axiology of criminal procedure. In administrative law, the notion of dispute has traditionally referred to disputes concerning the level of authority. Without detailed consideration of the link between the particular behavioural patterns (in particular, that of dispute and conflict) and the particular areas of normative regulation we may, following A. Korybski's suggestions, confirm their existence in each of the areas, whereby the extent of their occurrence varies. More on this issue: A. Korybski, O pojęciu sporu w prawoznawstwie: kilka uwag do dyskusji, [in:] Polska lat dziewięćdziesiatych: przemiany państwa i prawa. Materiaty z konferencji, Lublin - Kazimierz, 24-25 czerwca 1999 r., ed. T. Bojarski, Lublin 1999, pp. 274-277.

${ }^{4}$ Birth of a conflict implies three possible reactions of the parties to the conflict: 1) taking actions aimed at conflict avoidance, 2) subordination to the demands of the opposite party, and 3) entering into the conflict. A. Korybski, Alternatywne rozwiazywanie..., p. 28. As the consequences of entering into a conflict may be associated with social disorganisation, the behaviours of the parties to the conflict are typically regulated in a normative way. This enables the parties to base their demands on legal argumentation and makes it possible for the state to control the course of the dispute. More on this issue, inter alia: A. Kalisz-Prakopik, Alternatywne rozwiazywanie sporów - recepcja rozwiąań czy globalizacja koncepcji?, [in:] Filozofia prawa wobec globalizmu, ed. J. Stelmach, Kraków 2004, pp. 177-178.

${ }^{5}$ Furthermore, it must be mentioned that in the extensive literature devoted to dispute resolution and resolution there have been many attempts at structuring the mechanisms and ways of dispute control. For example, S. Roberts distinguishes between the rule-centred paradigm based on external rules and processual paradigm, based on the rules adopted by the parties to the dispute. See: S. Roberts, The study of dispute (p. 10-13), quoted in A. Korybski, Alternatywne rozwiazywanie..., p. 30. 
to the dispute. ${ }^{6}$ The decision making processes within the framework of dispute resolution are characterized by peaceful and non-authoritarian autonomous decisions made as a result of engagement of the parties or with participation of a third party. ${ }^{7}$ An example of the first form is the decision making process of adjudication i.e. the judicial type of application of law (perceived as the model administrative and managerial type). As to the second form, an example can be the decision making process within the so-called alternative forms of dispute resolution (mediation).

As I have already mentioned, the decision making processes within the mechanism of conflict control are united by the common goal i.e. levelling various types of conflict situations (incl. by establishing the legal consequences of the relevant factual states), with the reservation that their paths towards the goal run slightly different courses. The difference between the processes can be characterised by reference to the criteria (adopted in the literature and in this article) that differentiate the basic types of application of law, whereby the point of reference for further analysis is the model judicial type of application of law encompassing the broad decision making process (incl. the control and execution phases).

The first criterion that differentiates decision making processes within the particular types is the indication of the subject/entity that has the authority to make the dispute-ending decision. Within the particular types of application of law i.e. the judicial and administrative types, the entities/subjects include, respectively, courts, public administration bodies as well as entities that manage particular organisational entities. In the case of the decision making process within mediation, the entities making the dispute-ending decision are parties to the dispute themselves. Consequently, whereas in the basic types of application of law the decision is made by a party external to the conflict, in mediation and its decision making process disputes are resolved through decisions made by the decisions' addressees. This also means that the decisions are of an autonomous character.

The general authority to make decisions is to be sought in the norms that regulate the possibility of settlement within the given type of mediation. ${ }^{8}$ Subse-

${ }^{6}$ Ibidem, s. 32. Also quoted in A. Korybski, i.a.: A. Kalisz, E. Prokop-Perzyńska, Mediacja cywilno-prawna w kontekście uregulowań polskich i europejskich, [in:] Alternatywne formy rozwiazywania sporów w teorii i w praktyce. Wybrane zagadnienia, eds. H. Duszka-Jakimko, S.L. Stadniczenko, Opole 2008, passim; A. Zienkiewicz, Studium mediacji. Od teorii ku praktyce, Warsaw 2007, p. 22.

${ }^{7}$ More on this issue: A. Korybski, Alternatywne rozwiazywanie..., p. 32.

${ }^{8}$ By indicating the type of mediation I am considering inclusion of the decision making process to the criterion of legal relations regulation with the reservation, however, that civil mediations will be the point of reference here (including business and labour disputes) and criminal disputes (including cases involving minors). Lack of reference to mediation in administrative and judicialadministrative cases is due to the fact that these "diverge" from the features typically found in the decision making process within mediation. More on this issue: A. Kalisz, Quasi-mediacyjność 
quently, the decisions are more concretely defined (in terms of time and subject) through a decision of a law-applying body that directs the dispute to mediation, or through a decision of the parties to the dispute themselves (civil mediation, based on which the parties decide to resolve the dispute resulting from the legal relations between them before the dispute is directed to court). Such a situation is different than in the case of the basic types of application of law, where the decision making authority is of general character in the managerial type (e.g. it results from task implementation), while in the case of the judicial type it is of a defined character: the location, time and subject are specified. ${ }^{9}$

The position of the decision making entity within mediation and its decision making process is different than the position of decision making entities in the basic types of application of law. The key differentiators are the rules on which the decision making process is based. These rules define the specificity of the form of dispute resolution i.e. the rules of voluntary participation, acceptability and conflict autonomy. The essence of the first rule is expressed by the lack of external coercion, both regarding the participation of the parties in the mediation process and regarding a settlement that takes into account the mutual interest of both parties. Using this form of dispute resolution, reaching an agreement, defining the particular procedural rules for the discourse between the parties and resignation from mediation at any moment of the process are fully dependent on the decisions and will of the parties. ${ }^{10}$ The voluntary character is a feature that most clearly distinguishes this form of dispute resolution from dispute resolution within the basic types of application of law. The voluntary character is also closely linked with the rule of acceptability of mediation. The essence of this rule is that it is necessary for the parties to express consent not only regarding the person of the mediator ${ }^{11}$ but also regarding the adopted procedural rules and the content of the consensus. The rule of conflict autonomy, in turn, means that parties to the conflict are perceived as "owners" of the dispute, which enables them to fully manage the dispute and

postępowania mediacyjnego przed sądami administracyjnymi, [in:] Arbitraż i mediacja. Praktyczne aspekty stosowania przepisów. Proceedings from the Conference in Iwonicz Zdrój, October 18-20, 2007, Rzeszów 2007.

${ }^{9}$ L. Leszczyński, Zagadnienia teorii stosowania prawa. Doktryna i tezy orzecznictwa, Cracow 2004, pp. 1921.

${ }^{10}$ More in this issue, inter alia: R. Cebula, Mediacja w polskim prawie cywilnym, „Mediator”

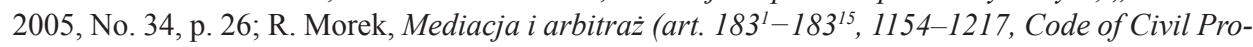
cedure). Commentary, Warsaw 2006, p. 40.

${ }^{11}$ The practical element of the voluntary character principle and the rule of acceptability is based on the psychological mechanisms that direct human behaviour. Self-directed conflict resolution by the parties breeds satisfaction and accountability for the implementation of the consensus P. Waszkiewicz, [in:] Mediacje. Teoria i praktyka, eds. E. Gmurzyńska, R. Morek, Warsaw 2009, p. 96. 
each stage of the decision making process within mediation. ${ }^{12}$ The position of the decision making entity within mediation's decision making process is therefore equal, rule-based as regards the form of dispute resolution and particular procedural rules adopted by the parties themselves.

Contrary to the legally defined position of decision making entities in the basic types of application of law, the position of the decision making entity within mediation is not formalised. The feature of independence and sovereignty situates courts within the judicial type of application of law, while the administrative and judicial types are independent but also obliged to implement the policy of their supervisory organs, within which the entities realise their duties and take accountability for the tasks imposed on their addressees. ${ }^{13}$ Additionally, the indicated decision making entities within the above mentioned types of application of law are also obliged to act effectively and promptly when making decisions as they are in the position of authority vis a vis the addressees of the decisions (within the managerial type the authority is also derived from professional hierarchy $\left.{ }^{14}\right)$.

\section{ROLE OF MEDIATOR IN THE DECISION MAKING PROCESS. LEGAL CIRCUMSTANCES OF THE DISPUTE RESOLUTION}

When we describe the position of the decision making entity within mediation and its decision making process, we must consider the participation of a party external to the dispute's parties i.e. the mediator. The mediator's role is predominantly based on actively supporting the parties at each stage of the decision making process, until the parties make a dispute-ending decision. In particular, the mediator's support is expressed through the following: facilitation of communication and enabling the discourse between the parties thanks to appropriately selected tactics and mediation strategy matching the dispute's dynamics and specificity, organisation of the decision making environment (this may include preparation of specific procedural rules ${ }^{15}$ ), diagnosis of interests and actual needs of the parties. As to the latter, the mediator enables the parties to create a "framework" for a future settlement by drawing the parties' attention to their common ${ }^{16}$ interests. ${ }^{17}$ Additionally, the mediator's task is also to draw the parties' attention to the feasibility of the dispute solution proposals they are offering ${ }^{18}$ (although the

${ }^{12}$ More in this issue, inter alia: A. Zienkiewicz, op. cit., p. 25; A. Jakubiak-Mirończuk, Alternatywne a sądowe rozstrzyganie sporów sądowych, Warsaw 2008, p. 45.

${ }^{13}$ L. Leszczyński, Zagadnienia teorii stosowania ..., pp. 19-21.

${ }^{14}$ Ibidem.

${ }^{15}$ A. Jakubiak-Mirończuk, op. cit., p. 45.

${ }^{16}$ Ibidem.

${ }^{17}$ A. Korybski, Alternatywne rozwiazywanie..., p. 117.

${ }^{18}$ A. Jakubiak-Mirończuk, op. cit., p. 45. 
effectiveness of the mediator's activity in this respect seems to depend on his/her legal knowledge).

The mediator's position as an active external party supporting the decision making process is not super-ordinate to the parties to the dispute (lack of authority) and is, in general, not associated with any form of management or professional hierarchy. The mediator is an intermediary in the mediation process and remains impartial, independent and neutral; his/her position must be perceived differently than the corresponding rules which define the position of entities within the basic types of application of law, i.e. it must perceived with the specific nature of mediation in mind. The first rule means that the mediator has to retain an objective perspective on the parties to the mediated dispute. ${ }^{19}$ An impartial mediator performs his/her mediation activities in a manner that does not indicate support, bias or favour towards one of the parties. The obligation to remain impartial is associated with the necessity to ensure a balance between the parties during the mediation (through, inter alia, guaranteeing the same number of meetings with each party, the same extent of opportunity to express opinion etc.). ${ }^{20}$

The further rules that guarantee impartiality are the rules of independence and neutrality. The essence of independence is that mediation function must be performed in a way that focuses on avoidance of situations leading to potential conflicts of interests. ${ }^{21}$ An external third party cannot condition the way he/she performs his/her activities on personal relationships or external/internal influences or personal preferences. The principle of mediator's neutrality is reflected in the mediator's attitude to the dispute and its subject matter. ${ }^{22}$ The mediator is obliged to refrain from any suggestions on the contents of the settlement ${ }^{23}$, and must have no vested interests (of various sorts) in the final content of the settlement shaped by the parties. ${ }^{24}$

Mediation is a form of reaction to a conflict between the parties that consequently turns into a dispute. Generally speaking, the decision making process in mediation is launched as in the judicial type of application of law, i.e. through an external stimulus (the decision of a law-applying body that decides upon the dis-

${ }^{19}$ More on the rule of mediator's impartiality: R. Morek, op. cit., pp. 56-58. In the literature, impartiality is treated as, among others, the "rule stating that everybody has the equal right to realise their interests". P.W. Taylor, Universalizability and justice, [in:] Ethics and social justice, ed. H.E. Kiefer, M.K. Munitz, Albany, N.Y. Commentary, Warsaw 1970, p. 144. Quoted after: Z. Łyda, Bezstronność arbitra a zakaz ,zainteresowania w sprawie”, „Państwo i Prawo” 1996, No. 2, p. 46.

${ }^{20}$ Ibidem, pp. $45-54$.

${ }^{21}$ R. Morek, op. cit., p. 57.

${ }^{22}$ A. Kalisz, A. Zienkiewicz, Mediacja sądowa i pozasądowa. Zarys wykładu, Warsaw 2009, p. 61.

${ }^{23}$ G. Skrzypczak, Prawnik a sposoby rozwiąywania sporów, „Monitor Prawniczy” 2004, Vol. 4, p. 198.

${ }^{24}$ P. Waszkiewicz, [in:] Mediacje. Teoria ..., p. 97. 
pute to direct the dispute to mediation). Contractual mediation is a similar case: although it actually is a separate decision making process, it is still associated with the process of application of law through its outcome. The settlement reached by the parties may be confirmed by court as a result of filing an appropriate application by the addressees of the decision (in civil disputes), or by including the contents of the agreement in the contents of the court's ruling (criminal law, mediation involving minors). What is characteristic of mediation's decision making process is the fact that the condition for the process' trigger is the consent expressed by both parties to carry out the process (following from the principle of voluntary nature of mediation).

The nature of mediation's decision making process is connected with the particular dispute, whereby the course of the process is based on entirely different principles than the judicial or managerial decision making process (that are typically associated with a lack of dispute). The nature of mediation is not contradictory or inquisitive (as in the judicial decision making process), and its decision making process is not highly formalised as in the basic types of application of law (apart from the key principles of voluntary nature, acceptability, confidentiality and conflict autonomy). The decision making process in mediation is limited to a discourse-based statement of facts that are the subject of the dispute and to the contents of the dispute-ending decision in light of the established facts.

In order to shed more light on the difference between the character of the decision making process in mediation as opposed to the decision making processes in other types of application of law (in particular - the judicial type) it is worth indicating an analysis of the differences in the concept of communication applied in both types. In mediation, discourse is convergent and its fundamental objective is to direct the parties towards an agreement by forging an atmosphere of collaboration "based on shared standards, evaluations and practice". ${ }^{25}$ A means for achieving the objective of the discourse is a conversation between the parties ${ }^{26}$, perceived as direct exchange of information aimed at creating an "awareness of a shared vision of communication practice". ${ }^{27}$ An indirect communicative objective within convergent discourses is to create a cultural community, wherein the discourse participants exchange information on their varied understanding of particular signs (this may be referred to as the facts - Author's note) and subsequently define the shared meaning of the signs. ${ }^{28}$

${ }^{25} \mathrm{~W}$. Cyrul, Wplyw procesów komunikacyjnych na praktykę tworzenia i stosowania prawa, Warsaw 2012, p. 190.

${ }^{26}$ Ibidem, p. 323.

${ }^{27}$ Ibidem, p. 190.

${ }^{28}$ According to W. Cyrul, the key reason for misunderstandings is the lacking skill of interpretation of messages presented by the opponent against the actual interests, opinions, needs etc. More on this issue: ibidem, pp. 190-191. 
Within the convergent discourse, communication is not limited by strict rules (lack of the coherence requirement) and the recipient can both ask questions and receive explanations. His/her subsequent message may be limited to adding further information to the body of common knowledge (which, consequently, may lead to removal of the contradiction, occurrence of a collision is not a requirement). The aim of the discourse (i.e. reaching an agreement) implies the necessity to retain coherence within communicative acts: subsequent messages of the parties must be logically interrelated. The participants of the discourse must also be ready to change their conceptual systems and align their messages with their actions. ${ }^{29}$ The language of communication is dependent on the individual speech acts, whereby legal language is combined with the specific normative language. ${ }^{30}$

The communication that takes place within the process of application of law and its basic types of application of law has features of transmission discourse characterized by different assumptions, objectives, and means of realization. ${ }^{31}$ The key objective of the communication is to process information based on the rules of the system that ensure the system's internal coherence and instrumental effectiveness of the massages conveyed and expressed in the behaviours of the recipients of the messages. The message's sender has influence on the message's content, while the receiver is only equipped with the capacity to receive and decode information; this means that the volume of information is unilaterally determined. The message's effectiveness depends on its alignment with the strict rules of the system. Therefore, as W. Cybul indicates, transmission discourse excludes the possibility of direct and equal communication between the interlocutors ${ }^{32}$, and tends towards inquisitive forms of dispute resolution as well as the subsumptionbased character of legal ${ }^{33}$ reasoning. ${ }^{34}$

When we consider the next differentiating criterion that distinguishes the decision making process in mediation from decision making processes in the basic types of application of law, we must recognize the similarity in terms of the form

${ }^{29}$ More on this issue: ibidem, pp. 192-193.

${ }^{30}$ More on this issue: ibidem, p. 132.

${ }^{31}$ More on this issue: ibidem, p. 323.

${ }^{32}$ More on this issue: ibidem, pp. 187-190.

${ }^{33}$ More on this issue: ibidem, p. 323.

${ }^{34}$ The differences between the basic rules applied in the discourses under study translate into different concepts of rationality and knowledge. Communicative rationality in the transmission type of communication combined the discourse with technological and instrumental rationality, while in the convergent type of communication it is associated with discoursive rationality, thus facilitating "not only going beyond the division into practical and theoretical mind, but also opening oneself to the social and affective function of language (ibidem, p. 196 and quotes therein). 
and character of the decision. ${ }^{35}$ As in the judicial, administrative and managerial types, the dispute-ending decision is an individual and specific decision drawn up in writing. Contrary to the managerial and judicial types of application of law, decisions made as a result of mediation do not formally require drafting a (written) justification. However, the justification is created during the process as a result of the interaction between the parties. While in the case of the basic types of application of law the decision results from a qualification of the factual state based on legal norms (more on this issue later in this article), the dispute-ending decision within mediation may be based on non-legal social norms internalized by the parties - with the reservation that for the agreement to be effective, compliance with the legally binding norms is necessary.

Yet another differentiating criterion is the control over the decision taken. In the case of mediation and its decision making process, the control is difficult to define. In the basic types of application of law we deal with instance-based control executed by courts and administrative bodies. In mediation, the control takes the form of a "confirmation" of the decision made by the parties. The "confirmation" takes various shapes, depending on the type of the dispute in question. In the case of agreements in civil disputes it is limited to a verification of compliance of the decision's contents with the content of the binding legal norms. In the case of mediation in criminal cases (and cases involving minors) the control is exercised if the content of the settlement is "taken into account" before the court's ruling. Referring the above to the various types of mediation initiation: if the process is initiated by a stimulus from a law-applying body (the court) it may be described as internal (albeit without the capacity to appeal), while in out-of-court mediation, the confirmation is external, i.e. the stimulus comes from a different party (e.g. a party to the dispute and addressees of the decision made as a result of mediation).

\section{PHASES OF MEDIATION AND JUDICIAL APPLICATION OF LAW. OPPORTUNITIES FOR MEDIATION}

In literature we may come across different approaches to the course of the decision making process in mediation, depending on the adopted theoretical perspective. In order to be consistent with the model of the decision making process

${ }^{35}$ At this point id must also be indicated that the content of the dispute-ending decision in mediation may be of twofold character: that of a compromise or consensus. A compromise consists in "working out a decision accepted by all negotiation participants at the cost of concessions made by each party. Such a decision results in agreeing that a full realisation of particular demands (interests) in the particular conflict situation is impossible". Consensus, in turn, is a "unilateral decision that creates the rules for cooperation or conflict resolution; in the latter case the content of the decision is a collaboration formula that refers to the convergent part of the demands (interests) of the parties to the negotiation". H. Groszyk, A. Korybski, Konflikt interesów..., p. 103. 
of application of law adopted in this volume I will characterize the decision making process with reference to its particular phases, i.e. the preparatory phase, content formulation phase, control phase, appeal phase and execution stage.

Starting from the first one in the order mentioned above: it encompasses fact finding and definition of the legal status of the case. Here, we must indicate the difference between the decision making process in mediation and the one in the basic types of application of law (in particular, with reference to the model type i.e. the judicial type). In mediation's decision making process the fact finding stage is, in general, of lesser importance. ${ }^{36}$ This is linked to the prospective direction given to the dispute-ending decision. Dispute resolution in this mode is focused on the aims and interests of the parties (and their relations in the future), while a retrospective search for arguments of the parties is of lesser ${ }^{37}$ importance. $^{38}$ Consequently, the fact finding stage in the case of mediation seems to be limited to two elements. The first one is presentation by each party of subjective information on their perception of the facts that are the basis for the conflict. The second one is an attempt at "agreeing" a common way of perceiving the information with the opponent's point of view taken into consideration. In the last phase, an important role is played by the mediator: with the awareness of how the parties perceive the facts (gained in the first phase), he/she can now direct the parties to focus on what they have in common.

As in the basic types of application of law, the fact finding phase does not constitute legal reasoning. Differently from the basic types, the phase is not formal: apart from the necessity to realise the principles of mediation (confirmed in legal provisions), the definition of the remaining rules of mediation rests with the parties themselves. In this context it must be noted that the decision making entity in mediation's decision making process is neither bound by the principle of material nor formal truth nor by the procedural obligation to make a decision. Therefore, the decision on the facts of the case is of consensus character.

The next stage within the preparatory phase is validation. In the case of mediation it seems to comprise the following: selection by the parties of the source of reconstruction of the basis for the future decision, interpretation of the source, and subsequent consensus-based agreement of the source with participation of the

\footnotetext{
${ }^{36}$ Although, depending on the adopted mediation strategy (generally understood as a way of facilitating the mediation discourse by the mediator), the activity seems to dominate over the remaining phases of the process. An example here can be the narrative mediation strategy with powerful psychological grounding.

${ }^{37}$ A. Kalisz, A. Zienkiewicz, Wymiar sprawiedliwości a mediacja, [in:] Rozdroża sprawiedliwości we współczesnej myśli filozoficzno-prawnej, eds. B. Wojciechowski, M.J. Golecki, Toruń 2008, p. 270.

${ }^{38}$ L.L. Fuller, Mediation - its forms and functions, "Southern California Law Rewiev" 1970/71, Vol. 44, pp. 307-308. Quoted after: A. Korybski, Alternatywne rozwiazywanie..., p. 106.
} 
mediator. As it has already been mentioned, in mediation the decision can be made beyond the framework of legal provisions. Sometimes its extent can be larger and based on extra-systemic norms i.e. norms from other normative systems of social control. There also seem to be no barriers for the parties to take into account other sources, e.g. decisions on application of law. However, as the enforceability and effectiveness of the content of the settlement depends on the positive outcome of its confirmation or "consideration" in the control phase (see below), selection of other sources (including non-legal norms) must not include any sources that contradict the binding legal norms ${ }^{39}$ In the adjudication-type of decision making, the point of reference is supplied by the binding legal norms, not the interests of the parties. A court's task is to define which party has a justified claim from the point of view of the binding norms (predominantly legal norms). ${ }^{40}$

Interpretative reasoning in the decision making process of mediation, considered in the context of the model decision making process of application of law (also encompassing validation), appears to play a less important role. ${ }^{41}$ Additionally, the "intensity" of the stage of interpretation of legal provisions in mediation depends on the fact that the source of the decision is rooted in legal provisions, and on the level of expertise of the parties to the mediation and the mediator. If legal expertise of the parties and the mediator is not sufficient, the reasoning that accompanies reconstruction appears to be intuitive. The above comment also applies to pre-reconstruction intuitions that enable the entity to make an initial evaluation of where the object of the dispute lies in the legal system based on the initial pieces of information about the subject matter of the dispute. Apart from the two factors that influence the "expertise" of interpretative reasoning, systemic and objective-functional sources prevail in the case of non-systemic sources serving as the basis for reconstruction. If the parties to the dispute or the mediator possess the relevant expertise, the reconstruction appears to diverge from the one applied by law-applying bodies within the basic types of application of law.

The subsumption phase within mediation's decision making process, as indicated by A. Zienkiewicz, is of reverse character when compared against the model decision making process within the judiciary type of application of law. The phase's task is not to adjust the facts associated with the behaviour of the parties in the past to the normative basis for the decision as interpreted from the legal sources (as the only or prevailing source). Rather, its task is to evaluate whether

\footnotetext{
${ }^{39}$ Art. $183^{14} \S 3$ of the Code of Civil Procedure - according to the article, "the court may refuse to grant enforceability or confirm the agreement reached with a mediator is the agreement is in conflict with the law or norms of social co-existence, or aims at a circumvention of the law, or when it is not understandable of self-contradictory". A. Kalisz, A. Zienkiewicz, Wymiar sprawiedliwości..., p. 270.
}

${ }^{40}$ H. Groszyk, A. Korybski, Konflikt interesów a prawo, Warsaw 1990, p. 107.

${ }^{41}$ More: L. Leszczyński, Zagadnienia teorii stosowania prawa ..., p. 21-28. 
the options of solutions agreed by the parties fit within the content of the consensus reached in the previous stages, i.e. the "mediation norm". ${ }^{42}$ The evaluation is not aimed at implementing the principle of material truth or indicating the "strictly defined" legal consequences of the behaviour of the parties (as in the judicial type of application of law). Instead, it is aimed at indicating the future relation between the parties to the dispute, temporarily distorted by the conflict - from the point of view of the jointly developed justice formula. This is so because dispute settlement in mediation is based on consensual justice. The validity of the consensus reached through mediation is to be considered in the context of the discourse's outcome after proceeding in accordance with a mutually accepted course of action that includes a similar (if not exactly the same) level of activity of both parties to the dispute. ${ }^{43}$

As indicated in the relevant literature (and with reference to the subsumption stage within mediation), the evaluation of a given solution option as a fair or just solution occurs when it is accepted by both parties to the dispute and takes into account their interests as well as needs, is not self-contradictory, is understandable and feasible, and, consequently, aligned to the principles of social compact. ${ }^{44}$ This means that the internal attributes of the judicial type of application of law (certainty and predictability of decisions) are of secondary nature due to the principle of autonomy of conflict. "External" attributes may be interpreted by the parties differently than in the interpretation of the entity acting within the judicial type of application of law and within the concept of the "judicial truth". ${ }^{45}$

The phase of content formulation is "continuous" in the case of mediation. This means that is does not constitute a separate stage as in the basic types of application of law (although even in the basic types the phases permeate one another), but is still a consequence of the preliminary phases. Due to the lesser importance of the fact finding stage, the phase in question holds the dominant position. The decision content formulation phase seems to encompass gathering the mutually accepted options of dispute settlement (aligned to the adopted formula of justice) that specify the future commitments of the parties to the dispute and fit in the social relationship between the parties. Mediation justice, as has already been mentioned in the description of the subsumption phase, is of subjective and individualised character and these features are reflected in the dispute-ending decision.

${ }^{42}$ A. Kalisz, A. Zienkiewicz, Wymiar sprawiedliwości ..., pp. 269-270.

${ }^{43}$ Along this line of thinking; A. Jakubiak-Mirończuk, op. cit., p. 127.

${ }^{44}$ More on this issue: A. Zienkiewicz, op. cit., s. 244.

${ }^{45}$ For this reason A. Kalisz, A. Zienkiewicz claim that in the case of decision making in mediation, there is realisation of law rather than application of law. More on this issue: A. Kalisz, A. Zienkiewicz, Wymiar sprawiedliwości..., p. 272. 
Justification of the decision in mediation, just as in the other types of application of law, encompasses all components of the decision making process yet is distinguished by features resulting from the specificity of the mediation process. This means that a less important role is played in the contents by fact finding arguments (as the decision pertains to a future state) and legal arguments (due to the lack of necessity to base the decision on the contents of legal norms). The fact that the decision making process in mediation is not formalised leads to the lack of obligation to draft a justification of the contents of the settlement in writing. A discoursive character of the process based on convergent communication model implies rationality of the decision vis a vis its addressees (parties to the discourse) within the adopted mode of communication (communicative model of argumentation ${ }^{46}$ as well as communicative rationality $\left.{ }^{47}\right)$.

The next phases in mediation's decision making process are the appeal and control stage. These stages fit within the decision making process of the judicial type of application of law. Evaluation of the content of the settlement is made from the point of view of legality (similarly to external control in the judicial and administrative types) as its feasibility. The appeal stage matches the appeal stage in the judicial type if the content of the settlement is taken into account in the content of the court's ruling (in criminal law mediation and cases involving minors), or in the form of enforceability clause in civil mediations.

The final phase in the decision making process of application of law i.e. the execution phase is varied in mediation, depending on the adopted mode of initiation of mediation. In the case of initiation upon motion of a relevant law applying body (whereby the motion is conditioned by the parties' agreement to have the dispute resolved through mediation) and after a positive outcome of the control phase (enforceability clause for the settlement in the case of civil mediation or content contained in the ruling in criminal cases), the implementation of the phase takes place in the way which is appropriate for the given basic type of application of law. If, however, the decision making process in mediation is associated with the process of application of law (contractual mediation) and if the parties have not filed for court approval of the settlement, the execution phase starts by initiating a separate process of application of law (i.e. by filing the relevant claim to enforce execution of the liability) if one of the parties to the settlement has not fulfilled the provisions contained in the settlement.

In summary of this article it must be noted that the decision making process within mediation (one of the dispute-settling decision making processes) shares

${ }^{46}$ More on the communicative model of argumentation and the vision of law connected therewith in: L. Morawski, Argumentacje, racjonalność prawa i postępowanie dowodowe, Torun 1988, pp. $78-104$.

${ }^{47}$ Cf. A. Kalisz, A. Zienkiewicz, Wymiar sprawiedliwości..., p. 272. 
the objective of levelling off the conflicts taking place in the society with the decision making process of the basic types of application of law. This article draws a comparison between the two major decision making processes and lists the differentiating criteria, thus showing that there are common elements between the processes (the situation of dispute, process initiation) as well as different elements (the position of the decision making entity, rules and procedural principles, validation phase, reconstruction phase) as well as the "permeating" elements (decision content formulation phase in criminal mediation and in cases involving minors, the control phase, the execution phase).

The sources of the discrepancies appear to stem from the different modes of dispute settling, within which the decision making processes "function", i.e. adjudication (the judicial, administrative and managerial type) and resolution (the decision making process in mediation). Despite the significant differences, the decision making processes co-exist within the contemporary judiciary system, they permeate each other and complement each other ${ }^{48}$ (e.g. in the case of the law applying body's decision to send a given case do mediation and the subsequent inclusion of the content of the settlement in the decision of the law applying body), thus creating a continuum. ${ }^{49}$

\section{LITERATURE}

Cebula R., Mediacja w polskim prawie cywilnym, „Mediator” 2005, nr 34.

Cyrul W., Wpływ procesów komunikacyjnych na praktykę tworzenia i stosowania prawa, Warsaw 2012.

Gmurzyńska E., Morek R., Mediacje. Teoria i praktyka, Warsaw 2009.

Groszyk H., Korybski A., Konflikt interesów a prawo, Warsaw 1990.

Groszyk H., Korybski A., O pojęciu interesu w naukach prawnych (przegląd wybranej problematyki z perspektywy teoretyczno-prawnej), [in:] Pojęcie interesu w naukach prawnych, prawie stanowionym i orzecznictwie sadowym Polski i Ukrainy, eds. A. Korybski, M. Kostyckij, L. Leszczyński, Lublin 2006.

Jakubiak-Mirończuk A., Alternatywne a sądowe rozstrzyganie sporów sądowych, Warsaw 2008.

Kalisz A., Quasi-mediacyjność postępowania mediacyjnego przed sądami administracyjnymi, [in:] Arbitraż i mediacja. Praktyczne aspekty stosowania przepisów. Materiały z Konferencji Naukowej Iwonicz Zdrój 18-20 października 2007, Rzeszów 2007.

Kalisz A., Prokop-Perzyńska E., Mediacja cywilno-prawna w kontekście uregulowań polskich i europejskich, [in:] Alternatywne formy rozwiazywania sporów $w$ teorii $i$ w praktyce. Wybrane zagadnienia, eds. H. Duszka-Jakimko, S.L. Stadniczenko, Opole 2008.

${ }^{48}$ It is precisely due to the permeation and complementariness that I consider it possible to perceive the decision making process in mediation as a "sub-type" of the process of application of law. A detailed analysis of the structure and content of the process in the context of the differentiating criteria across the types of application of law and a significant level of dissimilarity is an argument to treat mediation as a distinct decision making process.

${ }^{49}$ Following the line of thinking in, inter alia.: L. Morawski, Proces sadowy a instytucje alternatywne, „Państwo i Prawo” 1993, No. 1, p. 13. 
Kalisz A., Zienkiewicz A., Mediacja sądowa i pozasadowa. Zarys wykładu, Warsaw 2009.

Kalisz A., Zienkiewicz A., Wymiar sprawiedliwości a mediacja, [in:] Rozdroża sprawiedliwości we wspótczesnej myśli filozoficzno-prawnej, eds. B. Wojciechowski, M.J. Golecki, Torun 2008.

Kalisz-Prakopik A., Alternatywne rozwiązywanie sporów - recepcja rozwiązań czy globalizacja koncepcji?, [in:] Filozofia prawa wobec globalizmu, ed. J. Stelmach, Cracow 2004.

Korybski A., Alternatywne rozwiązywanie sporów w USA, Lublin 1993.

Korybski A., O pojęciu sporu w prawoznawstwie: kilka uwag do dyskusji, [in:] Polska lat dziewięćdziesiatych: przemiany państwa i prawa. Materiaty z konferencji, Lublin - Kazimierz, 24-25 czerwca 1999 r., ed. T. Bojarski, Lublin 1999.

Kurczewski K., Spór i jego rozwiąanie, [w:] Konflikt i przystosowanie, Vol. IV, Warsaw 1979.

Leszczyński L., Zagadnienia teorii stosowania prawa. Doktryna i tezy orzecznictwa, Cracow 2004.

Łyda Z., Bezstronność arbitra a zakaz „zainteresowania w sprawie”, „Państwo i Prawo” 1996, No. 2.

Morawski L., Argumentacje, racjonalność prawa i postępowanie dowodowe, Torun 1988.

Morawski L. , Proces sadowy a instytucje alternatywne, „Państwo i Prawo” 1993, No. 1.

Morek R., Mediacja i arbitraż (art. 183 1-183 15, 1154-1217 KPC). Komentarz, Warsaw 2006.

Skrzypczak G., Prawnik a sposoby rozwiązywania sporów, „Monitor Prawniczy” 2004, No. 4.

Zienkiewicz A., Studium mediacji. Od teorii ku praktyce, Warsaw 2007.

\section{SUMMARY}

This article is an attempt at showing a separate nature of the decision making process within mediation, compared against the decision making process of application of law - in the context of the criteria that differentiate the particular types of application of law. The comparison leads to the conclusion that the analysed decision making processes, apart from their common objective (levelling of social conflict) feature some common elements (the situation of dispute, process initiation) as well as different elements (the position of the decision making entity, rules and procedural principles, source of normative reconstruction of the basis for the decision) as well as the "permeating" elements (decision content formulation phase in criminal mediation and in cases involving minors, the control phase of the decision making process, the execution phase). The sources of the discrepancies appear to stem from the different modes of dispute settling, within which the decision making processes "function", i.e. adjudication (the judicial, administrative and managerial.

\section{STRESZCZENIE}

Przedmiotem rozważań niniejszego artykułu jest próba wykazania odrębności procesu decyzyjnego mediacji w stosunku do procesu decyzyjnego stosowania prawa, w kontekście kryteriów różnicujących typy stosowania prawa. Porównanie to prowadzi do wniosku, iż analizowane procesy decyzyjne poza wspólnym celem (jakim jest niwelowanie konfliktów społecznych), posiadają elementy podobne (takie jak: sytuacja sporu, zainicjowanie procesu), zróżnicowane (takie jak: pozycja podmiotu decyzyjnego, zasady i reguły proceduralne, źródło rekonstrukcji normatywnej podstawy decyzji) oraz elementy ,przenikające się” (takie jak: faza formułowania treści decyzji w mediacjach karnych oraz nieletnich, faza kontrolna procesu decyzyjnego, faza wykonawcza). Źródeł wskazanych odmienności należy upatrywać w zróżnicowaniu scharakteryzowanych pokrótce sposobów opanowywania sporu, w ramach których „funkcjonują" procesy decyzyjne, tj.: rozstrzyganie (oraz wpisany $\mathrm{w}$ jego ramy typ sądowy, administracyjny i kierowniczy) oraz 
Pobrane z czasopisma Studia Iuridica Lublinensia http://studiaiuridica.umes.pl Data: 26/04/2023 16:13:22

rozwiązywanie - proces decyzyjny mediacji. Rozstrzyganie sporów wpisane $\mathrm{w}$ transmisyjny model komunikacji, cechujący się narzucaniem argumentów nadawcy komunikatu w celu wywołania wpływu na zachowanie odbiorcy, warunkuje konfrontacyjne nastawienie stron sporu (kontradyktoryjność procesu sądowego), rozwiązywanie zaś - z charakterystycznym dla siebie konwergencyjnym modelem komunikacji - zakłada równorzędność pozycji stron oraz wzajemne uznawanie argumentów każdej z nich (zasada akceptowalności, dobrowolności, autonomii konfliktu stron w mediacji). 